\title{
Scientific Argumentation and Deliberative Democracy: An Incompatible Mix in School Science? ${ }^{1}$
}

\author{
"In questions of science, the authority of a thousand is not worth \\ the humble reasoning of a single individual."
}

- Galileo Galilei

\begin{abstract}
The article investigates argumentation in science education, particularly in terms of how deliberative democracy is related to argumentation in school science. We use example political models of deliberative democracy are used to synthesize implications for argumentation in science teaching and learning. Some key questions guided our approach: How does democratic deliberation work and how does it relate to scientific argumentation? How might the principles and practices of deliberative democracy be used to facilitate scientific argumentation in science lessons? Are democratic values consistent or in conflict with scientific practices that demand an emphasis on particular evidence, claims and justifications? In order to address these questions, we cover practical pedagogical examples that illustrate the overlap and the tensions in argumentation in relation to deliberative democracy versus science.
\end{abstract}

\section{Introduction}

Across the world, there is an increasing acknowledgment of the importance of argumentation in science education. For example in the United States, the Next Generation Science Standards (NGSS Lead States, 2013) placed a strong emphasis on argumentation as a mediator in meaning making in scientific knowledge construction and evaluation. Argumentation involves the justification of knowledge claims with evidence and reasons (Erduran \& Jimenez-Aleixandre, 2007), and plays a key role in the coordination of theory and data articulated through inquiry (Toulmin, 1958). Toulmin's seminal book The Uses of Argument has paved the way for many science educators adapting his framework on argument for teaching and learning purposes (e.g. Erduran, Simon \& Osborne, 2004; Jimenez-Aleixandre, Buggalo-Rodriguez, \& Duschl, 2000).

Apart from the curricular and assessment calls for argumentation in school science, research literature has also emphasized the role of argumentation in science education (Driver, Newton \& Osborne, 1999; Kaya, 2013; Kaya, Erduran \& Cetin, 2012; Kelly \& Chen, 1999; Zohar \& Nemet, 2002). The trends in the top research journals in science education (e.g. Erduran, Ozdem \& Park, 2015) illustrate a significant increase in the articulation of argumentation for science

\footnotetext{
1 Sibel Erduran \& Ebru Kaya (2016) Scientific Argumentation and Deliberative Democracy: An Incompatible Mix in School Science?, Theory Into Practice, 55:4, 302-310, DOI: 10.1080/00405841.2016.1208067
} 
teaching and learning in the past 2 decades. Argumentation plays a role not only in scientific knowledge growth and scientific inquiry but also has relevance for broader educational goals such as informed citizenship. Everyday citizens in democratic societies have the power to influence decision-making about a whole range of socio-scientific issues (e.g. nuclear energy and genetic cloning). Hence it is vital for individuals to possess the ability to scrutinize scientific claims and evidence in the public domain. Science teachers can help improve students' argumentation skills by establishing norms of scientific argumentation in their classroom.

In this article, we concentrate on argumentation in school science and explore its relation to deliberative democracy. Research on argumentation in science education has typically drawn on a set of foundational theoretical perspectives from cognition, philosophy of science, linguistics, communication theory, social semiotics and sociocultural theories in framing argumentation for school science (Erduran, 2007). When argumentation in science education is related to concepts such as democracy, however, other foundational fields such as political philosophy are needed to inform theoretical frameworks that can be adapted to clarify the notion of deliberative democracy for educational purposes. Such theoretical appeal to political theory is virtually absent in argumentation studies in science education. The broad aim of the article, then, is to contribute to research on argumentation in science education by drawing on political theory framework in the context of deliberative democracy. In synthesizing perspectives on deliberative democracy and scientific argumentation, we are guided by some key questions: How does democratic deliberation work and how does it relate to scientific argumentation? How might the principles and practices of deliberative democracy be used to facilitate scientific argumentation in science lessons? Are democratic values consistent or in conflict with scientific practices that demand an emphasis on particular evidence, claims and justifications?

First, we present a brief overview of democratic goals in science education and focus on democratic deliberation as a relevant context for exploring the links to scientific argumentation. We then present some example models of deliberative democracy with implications for how argumentation can be implemented in classroom practice. Finally, our discussion illustrates the overlap as well as the tensions between democratic deliberation and scientific argumentation in school science.

\section{Democracy and Science Education}

In a democratic society, individuals can state their ideas and disagree with others' including the authorities'. They may use new evidence or interpret old evidence in a different way to support or refute ideas (Enslin, 2006). For instance, they can distinguish the validity of claims about genetic cloning and nuclear energy by assessing the quality of evidence presented. They can make judgments about whether a new war proposed by the government is warranted with evidence. Given the concept of 'democracy' is rather vast and has been studied extensively, we 
limit our discussion to "deliberative democracy". Through this focus, we investigate the potential intersection between argumentation and democracy in science education. Democratic values and norms have been subsumed within the science curriculum for decades (e.g. Fawn, 1998).

According to Gutmann and Thompson (2004), deliberative democracy affirms the need to justify decisions made by citizens and their representatives. In a democracy, leaders should give reasons for their decisions, and respond to the reasons that citizens give. The most important characteristic of deliberative democracy is its reason-giving requirement (Gutmann \& Thompson, 2004). Such "reason-giving" is also a major requirement in scientific argumentation (Toulmin, 1958). Our approach involves contrasting of some models of a particular instance of deliberative democracy to explore how these models can cohere or not with scientific argumentation.

The notion of "deliberative democracy" maintains that for a democratic decision to be legitimate, it must be preceded by authentic deliberation, not merely the aggregation of preferences that occurs in voting. This notion is consistent with the scientific ideals of deliberation in terms of debating evidence and justifications in reaching conclusions that are scientifically valid. Authentic deliberation is meant to be free from distortions of unequal political power, such as power a decision-maker obtained through economic wealth. Goals of science education in terms of decision-making and need to ensure that no distortions of unequal power should play a role, for instance, in terms of whose idea or whose evidence get attention in the classroom. In deliberative democracy, if the decision-makers cannot reach consensus after authentically deliberating on a proposal, then they vote on the proposal using a form of majority rule. As we will discuss in subsequent sections more, this approach would not hold in science and thus creates some tension between the assumptions of deliberative democracy and scientific argumentation.

\section{Models of Deliberative Democracy}

In this section, we exemplify models of deliberative democracy and explore their implications for argumentation in school science. We focus on 3 models proposed by Fishkin (2011), Cohen (1997, 1989) and Gutmann and Thompson (2004). These models are widely cited within political theory in articulating democratic deliberation. Given the scarcity in science education research of models of deliberation derived from political theory, we envisage the application of these models as holding the potential to open up a new territory of research that can be extended from theoretical investigation to empirical testing in school science.

\section{Fishkin's model}

James Fishkin, who has designed practical implementations of deliberative democracy for over 15 years in various countries (Fishkin, 2011; Fishkin, \& Laslett, 2003) described 5 characteristics essential for legitimate deliberation: 
1. Information: Accurate and relevant data is made available to all participants.

2. Substantive balance: Different positions are compared based on their supporting evidence.

3. Diversity: All major positions relevant to the matter at hand and held by the public are considered.

4. Conscientiousness: Participants sincerely weigh all arguments.

5. Equal consideration: Views are weighed using evidence, not on who is advocating a particular view.

The model can help inform argumentation studies in science education in defining the set of principles that would guide instructional decision-making as well as curriculum features. In particular, the five characteristics can act as a set of values and principles that would underpin how successful deliberation can be assessed for instructional purposes. For example, with respect to the characteristic of "equal consideration", a teacher might reflect, "have I encouraged my students to weigh views on evidence and not be biased with who is proposing the ideas in the classroom, including myself?"

\section{Cohen's model}

Joshua Cohen outlined conditions that he thinks constitute the root principles of the theory of deliberative democracy (Cohen, 1997; 1989). He outlines 5 main features of deliberative democracy:

1. An ongoing independent association with expected continuation.

2. The citizens in the democracy structure their institutions such that deliberation is the deciding factor in the creation of the institutions and the institutions allow deliberation to continue.

3. A commitment to the respect of a pluralism of values and aims within the polity.

4. The citizens consider deliberative procedure as the source of legitimacy, and prefer the causal history of legitimation for each law to be transparent and easily traceable to the deliberative process.

5. Each member recognizes and respects other members' deliberative capacity. This can be construed as the idea that in the legislative process, we "owe" one another reasons for our proposals.

According to Cohen, deliberative democracy is more than a theory of legitimacy. It is a body of substantive rights. The participants are free from any authority or requirements and they can act on the decision made. Parties to deliberation are required to state reasons for their proposals, and proposals are accepted or rejected based on the reasons offered. The aim of the deliberation is to reach a consensus. Through deliberation, acceptable reasons for all are sought for decisionmaking. If consensus is not possible, then the majority decision is accepted. Cohen's model of deliberative democracy offers a set of ideas that can be extracted and applied in science education as values and norms of deliberation. For example, "commitment to pluralism of values 
and aims" and "transparency" are values that can be imported for shaping the norms of argumentation discourse in science lessons.

\section{Gutmann and Thompson's model}

Amy Gutmann and Dennis F. Thompson's definition of deliberative democracy (Gutmann \& Thompson, 2004) captures the elements that are found in most conceptions of deliberative democracy. These authors defined it as "a form of government in which free and equal citizens and their representatives justify decisions in a process in which they give one another reasons that are mutually acceptable and generally accessible, with the aim of reaching decisions that are binding on all at present but open to challenge in the future” (p.7). They state that deliberative democracy has 4 requirements:

1. Reciprocal: The reasons should be acceptable to free and equal persons seeking fair terms of cooperation.

2. Accessible: The reasons must be given in public and the content must be understandable to the relevant audience.

3. Binding: The reason-giving process leads to a decision or law that is enforced for some period of time. The participants do not deliberate just for the sake of deliberation or for individual enlightenment.

4. Dynamic or Provisional: The participants must keep open the possibility of changing their minds, and continuing a reason-giving dialogue that can challenge previous decisions and laws.

Gutmann and Thompson's requirements for deliberative democracy could be criteria for establishing democratic values in science lessons. Some might cohere with scientific habits of mind (e.g. dynamic and provisional because scientists sometimes revise their ideas in light of new evidence) while others might not (e.g. accessibility of scientific evidence may be difficult to understand as it requires considerable theoretical knowledge).

\section{Applying Models of Deliberative Democracy in Argumentation in Science Education}

As Table 1 illustrates, models of deliberative democracy have potential applications in teaching and learning of argumentation in science lessons. As with the broader scope of deliberative democracy, participants are given voice and time to discuss evidence and propose claims on the basis of evidence. The features described implicitly underscore the importance of peer review, taking alternative arguments seriously and subjecting them to evidential scrutiny. As such, aspects of deliberative democracy are consistent with scientific cultures and thus have relevance and applicability for educational settings.

Table 1. Implications of deliberative democracy models for argumentation in science education. 


\begin{tabular}{|c|c|c|c|}
\hline $\begin{array}{l}\text { Model of } \\
\text { deliberative } \\
\text { democracy }\end{array}$ & Definition & $\begin{array}{l}\text { Potential } \\
\text { application in } \\
\text { science education }\end{array}$ & $\begin{array}{l}\text { Example applications for } \\
\text { argumentation in science } \\
\text { teaching and learning }\end{array}$ \\
\hline Fishkin & $\begin{array}{l}\text { Information } \\
\text { Substantive balance } \\
\text { Diversity } \\
\text { Conscientiousness } \\
\text { Equal consideration }\end{array}$ & $\begin{array}{l}\text { Instructional } \\
\text { approaches to } \\
\text { coordinating } \\
\text { classroom } \\
\text { discussions }\end{array}$ & $\begin{array}{l}\text { - Making accurate and } \\
\text { relevant data available for use } \\
\text { in science lessons; } \\
\text { - Seeking alternative ideas } \\
\text { from students and asking for } \\
\text { supporting evidence; } \\
\text { - Considering all ideas } \\
\text { relevant for class discussion } \\
\text { on the topic; } \\
\text { - Weighing all arguments } \\
\text { presented by students; } \\
\text { - Empowering evidence rather } \\
\text { than whose evidence in the } \\
\text { science lesson. }\end{array}$ \\
\hline Cohen & $\begin{array}{l}\text { Independent association } \\
\text { Institutional structures } \\
\text { Respect for pluralism of } \\
\text { values and aims } \\
\text { Transparency and } \\
\text { traceability } \\
\text { Deliberative capacity }\end{array}$ & $\begin{array}{l}\text { Norms and values } \\
\text { in classroom } \\
\text { discussions }\end{array}$ & $\begin{array}{l}\text { - Commitment to discussion } \\
\text { - Lesson structures and plans } \\
\text { allowing for debate; } \\
\text { - Respect for alternative ideas } \\
\text { in the lesson; } \\
\text { - Accepting argumentation as } \\
\text { a vehicle for evaluation of } \\
\text { ideas } \\
\text { - Making lesson objectives } \\
\text { and evaluations about } \\
\text { arguments accessible to all at } \\
\text { all times; } \\
\text { - Respecting others ideas } \\
\text { even when they are different } \\
\text { from your own. }\end{array}$ \\
\hline $\begin{array}{l}\text { Gutmann \& } \\
\text { Thompson }\end{array}$ & $\begin{array}{l}\text { Reciprocal } \\
\text { Accessible } \\
\text { Binding } \\
\text { Dynamic or provisional }\end{array}$ & $\begin{array}{l}\text { Criteria for } \\
\text { evaluation of ideas } \\
\text { in discussions }\end{array}$ & $\begin{array}{l}\text { - Agreement on reasons } \\
\text { - Public sharing of reasons } \\
\text { offered by all students; } \\
\text { - Ensuring that there is a } \\
\text { purpose to classroom } \\
\text { discussions; } \\
\text { - Adaptability of ideas in light } \\
\text { of evidence. }\end{array}$ \\
\hline
\end{tabular}

Consider the following example dialogue which illustrates how Fishkin's model of deliberative democracy might play out in a science classroom. Imagine that the teacher is engaging students about a task that investigates whether euglena is a plant or an animal cell. Euglena is a protist 
that has features of both plants and animals but students may have only been exposed to categories of living organisms as either plants or animals up to this point in their education. Thus there would be an opportunity for argumentation.

The teacher initiates the discussion by asking students what they observed about euglena:

T- What did you observe about euglena?

S1- Euglena is a plant cell.

S2 - I don't think euglena is a plant cell. It's an animal cell.

S3- I think euglena is really ugly.

T- Ok, you have different ideas about what euglena is. Why do you think euglena is a plant cell?

S1- It's a plant cell because it contains chlorophyll.

S2- Yes but don't you see that it moves when you look at it under the microscope? Animal cells move, not plant cells.

T- Ok, so S1 and S2, you have both observed that euglena has chlorophyll and it moves under the microscope, is that right? What's your evidence? S3, you think euglena is really ugly. Do you think euglena being ugly explains if it's a plant or an animal cell?

The students are given an opportunity to express their points of view and provide reasons for their ideas. She acknowledges that the students have different ideas and thus empowers their ideas without dismissing them. In terms of Fishkin's model, she gives equal consideration of ideas and respects diversity in the classroom. When the teacher asks "You have both observed that euglena has chlorophyll and it moves under the microscope, is that right? What's your evidence?" she is seeking alternative ideas from students and weighing all ideas equally. However not all ideas may be credible and she weighs the claims being made. She questions S3 in articulating whether or not the idea of euglena being ugly is relevant for deciding whether euglena is a plant or an animal cell.

Regarding the application of Cohen's model of deliberative democracy in science education, one implication is norms and values in classroom discussion. An example dialogue on the euglena topic illustrates how such norms and values can be established in a science lesson:

T- What did you observe about euglena?

$\mathrm{S} 1$ - Euglena is a plant cell.

S2 - What a stupid idea! I don't think euglena is a plant cell. Can you not see that it is moving?

T- S2, it is not nice to call your friend's idea stupid. We should respect each other's ideas even if they are different. Let's have a discussion about these different ideas. Remember our aim in this lesson is to debate ideas and give reasons for our ideas. So, 
we need to see which reason and evidence justify whether euglena is a plant or animal cell.

In this dialogue, $\mathrm{S} 1$ expresses that euglena is a plant cell as an answer to the teacher's question about euglena. Then the other student (S2) judges that S1's idea is stupid. In this case, the teacher says that "we should respect each other's ideas even if they are different." Thus the teacher addresses the issue of respect for alternative ideas in the lesson. Respect can be considered as part of the norms and values that need to be established in an argumentation lesson. After making lesson objectives clear for all students, the teacher encourages the students to have a debate on these different ideas by saying that "Remember our aim in this lesson is to debate ideas and give reasons for our ideas. So, we need to see which reason and evidence justify whether euglena is a plant or animal cell". Overall, the teacher expresses a commitment to a discussion.

Guttmann and Thompson's model of deliberative democracy has the potential to inform science teaching and learning about criteria for evaluation of arguments. Consider the following dialogue:

T- What did you observe about euglena?

S1- Euglena is a plant cell.

$\mathrm{T}$ - Why do you think euglena is a plant cell?

S1- Because it has chlorophyll.

S2 - I don't think euglena is a plant cell. It's an animal cell because it moves.

T- Ok good. So you both have reasons to think that euglena is a plant or an animal cell. How will we decide which one it is?

S3- Couldn't euglena be something else? Maybe it's neither plant nor animal but both.

When the teacher asks, "How will we decide which one it is?" she is inviting students to generate criteria for evaluation. Here S3 is expressing adaptability of ideas by evaluating arguments of S1 and S2 and proposing another criterion (i.e. neither plant nor animal cell but both) in deciding what euglena is. S3's approach demonstrates adaptability in terms of evidence that euglena has both plant and animal features. In other words, both S1 and S2's ideas are being considered but unlike S1 and S2, S3 is accommodating all existing evidence rather than ignoring some to maintain his position. Overall all arguments are accessible to the participants and there is public sharing of all ideas. The science examples used in the dialogues focus primarily on science subject knowledge. However it is also possible to consider science topics that are situated in socially relevant contexts. Typical topics can include genetic cloning and nuclear energy which would demand understanding not only of scientific concepts and skills of argumentation but also awareness of social values and ethos such as respect for human life and environment. Such 
instances can potentially be used as potentially useful cross-curricular links with social studies subjects.

\section{Conclusions and Implications}

Deliberative democratic models tend to generate ideal conditions of impartiality, rationality and knowledge of the relevant facts leading to a greater likelihood that the decisions reached are morally correct (Fearon, 1998). As Fearon argues, deliberative democracy has thus an epistemic value with moral consequences: it allows participants to deduce what is morally correct. Proponents of deliberative democracy consider deliberative democracy to produce more sympathy with opposing views; more respect for evidence based reasoning rather than opinion; and a greater chance for widely shared consensus, thus promoting social cohesion. It should be noted that such references to morality can be at odds with the scientific establishment given it is not the function of science to make recommendations on morality. Although science has a particular social ethos as part of a spectrum of features such as methods, practices and knowledge (Erduran \& Dagher, 2014), norms of social ethos are socially produced, negotiated, established and shared. For instance, ethical principles are often published in codes of conduct in scientific organisations and publications. These principles are institutionalised and do not rely on individual or relative accounts of morality.

While some features of deliberative democracy are compatible with argumentation in science education (e.g., argumentation activities are performed to convince others by justifying own arguments and opposing others' views in the classroom; argumentative discourse promotes evidence based reasoning in science lessons), others are in conflict. The preceding reference to morality in relation to deliberative democracy and science is one such example of conflict. Furthermore, there is a key distinction between the epistemic deductive value of deliberative democracy and school science argumentation. While deliberative democracy has an epistemic value with moral consequences allowing participants to deduce what is morally correct, moral codes or guidelines do not follow from scientific argumentation. In other words, morality is not an inherent component of science and thus cannot be derived from scientific reasoning practices such as argumentation. Furthermore, it is not necessarily the case that science will achieve public consensus and promote social cohesion. Consider, for example, the case of the theory of evolution by natural selection. Although there is now consensus within the scientific community about evolutionary theory, almost 150 years after the publication of Darwin's Origin of Species, there is no public consensus about evolution as a key explanatory framework for life. It is also not an inherent aspect of evolutionary theory to offer moral values that should underpin life, although some social theorists have applied evolutionary theory to the social sciences (e.g. Kevles, 1998). 
A criticism of most theories of deliberative democracy is that they do not address the problems of voting. Fishkin (1991) introduced a way to apply the theory of deliberative democracy to realworld decision making through what he calls deliberative opinion poll. In the deliberative opinion poll, a statistically representative sample of the nation or a community is gathered to discuss an issue. The group is then polled, and the results of the poll and the actual deliberation can replace a vote. While the problem of voting might be advanced as a failure for deliberative democracy, it is not directly relevant for norms of the scientific cultures. Although peer review

plays a significant role in how claims are assessed, it is not entirely on the basis of a majority vote that scientific knowledge gains its authority. It would be unthinkable, for instance, for scientists to hold a vote on evolutionary theory or the atomic model.

Students are knowledge consumers in science lessons because they are taught what the authority of scientific knowledge says or proposes rather than what students themselves produce based on democratic principles or values in a lesson. There is thus a tension between authoritative imposition of knowledge and democratic access to knowledge. Appeal to authority may be inevitable given the inaccessible nature of scientific knowledge and evidence, particularly from student's point of view. While we may settle for this as a given, we may still encourage instances in classroom discussions where students themselves also propose claims/opinions/ideas that are taken up for discussion, where the 'authority' now lies on the students, where student-centered discussions can take place.

\section{References}

Cohen, J. (1989). Deliberative Democracy and Democratic Legitimacy. In, A. Hamlin, \& P. Pettit (Eds.), The Good Polity. Oxford, UK: Blackwell. pp. 17-34.

Cohen, J. (1997). Deliberation and Democratic Legitimacy. In, J. Bohman \& W. Rehg (Eds.) Deliberative Democracy: Essays on Reason and Politics. Boston, MA: MIT Press.

Driver, R., Newton, P., \& Osborne, J. (2000). Establishing the norms of scientific argumentation in classrooms. Science Education, 84, 287-312.

Erduran, S., Ozdem, Y., \& Park, J. Y. (2015). Research trends on argumentation in science education: a journal content analysis from 1998-2014. International Journal of STEM Education, 2, 1-12. doi:10.1186/s40594-015-0020-1.

Erduran, S., \& Dagher, Z. (2014). Reconceptualizing the nature of science for science education: Scientific knowledge, practices and other family categories. Dordrecht, The Netherlands: Springer. 
Erduran, S., \& Jimenez-Aleixandre, M. P. (Eds.) (2007). Research in Argumentation in Science Education: Perspectives from Classroom-Based Research. Dordrecht: Springer. 285p. ISBN: 978-1-4020-6669-6)

Erduran, S., Simon, S. \& Osborne, J. (2004). TAPping into argumentation: Developments in the application of Toulmin's argument pattern for studying science discourse. Science Education, 88 , 915-933.

Fawn, R. (1998). The democratic argument for science curriculum reform in Britain and Australia: 1935-1945. Research in Science Education. 28, 281-299.

Fishkin, J. (2011). When the People Speak. Oxford: Oxford University Press. ISBN 978-0-19960443-2.

Fishkin, J., \& Luskin, R. C. (2005). Experimenting with a democratic ideal: deliberative polling and public opinion. Acta Politica, 40, 284-298. doi:10.1057/palgrave.ap.5500121.

Fishkin, J., \& Laslett, P. (Eds.) (2003). Debating Deliberative Democracy. New York: WileyBlackwell. ISBN 978-1405100434

Frearon, J. D. (1998). Deliberation as discussion. In, J. Elster (Ed.), Deliberative Democracy, pp. 44-68. Cambridge, UK: Cambridge University Press.

Gutmann, A., \& Thompson, D. (2004). Why Deliberative Democracy? Princeton University Press.

Jimenez-Aleixandre, M., Buggalo-Rodriguez, A. \& Duschl, R. (2000). 'Doing the lesson' or 'doing science': Argument in high school genetics. Science Education, 84, 757-792.

Kaya, E. (2013). Argumentation practices in classroom: Pre-service teachers' conceptual understanding of chemical equilibrium. International Journal of Science Education, 35, 11391158 .

Kaya, E., Erduran, S., \& Cetin, P. S. (2012). Discourse, argumentation, and science lessons: Match or mismatch in high school students' perceptions and understanding? Mevlana International Journal of Education, 2, 1-32.

Kelly, G. J., \& Chen, C. (1999). The sound of music: Constructing science as sociocultural practices through oral and written discourse. Journal of Research in Science Teaching, 36, 883915. 
Kevles, D. (1998). In the Name of Eugenics: Genetics and the Uses of Human Heredity. Cambridge, MA: Harvard University Press.

NGSS Lead States. (2013). Next generation science standards: For states, by states. Appendix H. Retrieved from http://www.nextgenscience.org/next-generation-science-standards

Thompson, D. F. (2008). Deliberative Democratic Theory and Empirical Political Science, Annual Review of Political Science, 11, 497-520. ISBN 978-0824333119

Toulmin, S. (1958). The uses of argument, Cambridge, UK: Cambridge University Press.

Zohar, A., \& Nemet, F. (2002). Fostering students' knowledge and argumentation skills through dilemmas in human genetics. Journal of Research in Science Teaching, 39, 35-62.

\section{Additional Resources}

1. Erduran, S., \& Pabuccu, A. (2012). Bonding chemistry and argument: supporting the teaching and learning of argumentation through chemistry stories. Teacher and Student Resource. Bristol: University of Bristol.

http://www.bristol.ac.uk/education/news/2012/63.html

This is a resources for teaching chemistry through argumentation with the use of narratives and stories at the high school level. The topics range from gas laws to organic chemistry. The resource has instructions for teachers including the learning goals and suggested sequence of a lesson activity, and for students including writing frames to support the writing of arguments.

2. Erduran, S., Yee, W. C., \& Ingram, N. (2011). Assessment and Practical Inquiry in Scientific Argumentation. Bristol: University of Bristol. Website of CPD and Teaching/Learning Resources. www.apisa.co.uk

The resource is for teacher educators interested in exploring the assessment aspects of teaching argumentation in science lessons. There are resources for series workshops that include some curriculum materials that integrate teaching and learning of argumentation with assessment of arguments.

3. Osborne, J., Erduran, S. \& Simon, S. (2004). Ideas, Evidence and Argument in Science. Video, In-service Training Manual and Resource Pack. London: King's College London.

The resources consist of (a) a manual for teacher educators to conduct in-service teacher training with science teachers, (b) teaching and learning resources aimed at middle-school science lessons, and (c) DVD consisting of video clips of middle school teachers conducting argumentation in science lessons. 